\title{
The social character of parental and adolescent television viewing: An event history analysis
}

\author{
HENK WESTERIK, KARSTEN RENCKSTORF, JAN LAMMERS \\ and FRED WESTER
}

Abstract

The amount of time that people spend on watching television is a matter of social concern. In the past, several approaches have been developed explaining why people expose themselves to television, most notably the Uses and Gratifications approach. Building on an action theoretical framework, it is argued that the influence of routinization and situational context of television viewing (including the role played by others) should receive more attention. This approach is then applied to media use in households, with an emphasis on how adolescents and parents influence each other's television viewing. Event history on data from 55 Dutch households (including 86 adolescents and their parents) show that the influence of parents and their adolescent children is reciprocal, that is, not only do parents influence their children, but children also influence their parents. This influence does, however, not increase during the teenage years, nor does parental influence diminish during those years.

Keywords: television viewing, uses and gratifications, everyday life, socialization, (reverse) socialization, event history analysis, action theoretical perspective

\section{Introduction}

It is a well-known fact that watching television has some long term consequences that most viewers would rather avoid. For instance, heavy viewing may increase body weight (e.g., Hancox, Milne, and Poulton, 2004; Hancox and Poulton, 2006), increase aggressiveness (e.g., Anderson and Bushman, 2002; Johnson, Cohen, Smailes, Kasen, and Brook, 2002), reduce educational achievement, reduce socioeconomic status and reduce well-being (Morgan, 1993; Comstock and Scharrer, 2001; Hancox, Milne, and Poulton, 2005; Vandewater et al., 2005). 
Still, many people spend a lot of time watching television. In the US, an average person ${ }^{1}$ watches 4.5 hours a day (Nielsen Media Research, 2005). In Western Europe, average viewing levels ${ }^{2}$ tend to be somewhat lower. In most of the larger countries (e. g., Italy, Germany, and the UK) average viewing is between 3 and 4 hours a day, while in smaller countries (e. g., Sweden, Denmark, the Netherlands, Luxemburg, or Switzerland) it is usually a little less than 3 hours a day (European Audiovisual Observatory, 2003). So, even in those smaller countries in Europe, watching television is still a significant part of everyday life.

\section{The uses and gratifications of television viewing}

Although television viewing is thus an activity of considerable social significance, there is still no single satisfying theory explaining why people watch television. Of course, Uses and Gratifications (U\&G) is the most widely applied perspective when it comes to explaining individual differences in media exposure (Bryant and Miron, 2004). However, this approach is not without limitations.

In its classical formulations (e. g., Katz, Blumler, and Gurevitch, 1974; Rosengren, 1974), media use was seen as an activity driven by subjectively felt beliefs about the anticipated consequences of media use and the desirability of these consequences (gratifications). In turn, these beliefs were seen as resulting from an underlying need structure, which itself was caused by the personal characteristics and social circumstances of the individual.

During the 1980s and 1990s many U\&G studies were published that elaborated on the role played by personal characteristics and social circumstances, resulting in models that became more and more complicated (Rubin, 2002). Another important development was the refinement of initial ideas about audience activity. Initially, scholars treated acts of media use as if they were brought about by free, discrete, conscious, and deliberate acts of will (cf. Katz et al., 1974; Blumler, 1979; Levy, 1983). Yet, this assumption was contradicted by research on audience flow which showed that individuals avoid laborious processes of media selection, in stead relying on undemanding routines of media use. This idea was then picked up by students of audience behavior (e. g., Rubin, 1984; Renckstorf, 1989), who argued that there are at least two modes of media use: a quasi-automatic 'ritualistic' mode in which an individual uses a medium as a routine response to a recurring problem; and an 'instrumental' mode, in which a medium is used in a self-aware and conscious way in order to deal with problems for which there are no instant solutions available. 
Another shortcoming of the initial U\&G approach was its tendency to pay little attention to the fact that television viewing is often directly affected by situational factors such as being at home, being involved in other activities, and being with others. This was recognized early on as shortcoming (Goodhardt, Ehrenberg, and Collins, 1975; Webster and Wakshlag, 1982) because such situational factors have the potential of blocking media use, even if such use is highly preferred or rooted in wellestablished routines.

A related point of criticism has been that $U \& G$ conceived media use in a manner that was too individualistic; it assumed that individuals make a free personal choice to expose themselves to a selection of media messages, and it ignored the influence of social contexts, for instance group processes (Elliot, 1974). Group processes are likely to occur within multi-person households as members decide about the availability of media equipment (e. g., newspaper and broadband subscriptions), living arrangements (e.g., the allocation of household tasks), and media use (e. g., who is in control of the remote in the living room; cf. Huysmans, 1996).

The importance of group processes for the explanation of program choices has been documented in several studies (for an early review and an example, see Webster and Wakshlag, 1982; see also Morley, 1986; Lull, 1988; Mutsaers, 1996). Subsequent research further shows that adult household members do not only influence each other's choice for specific program types, but also that their decisions to watch or to abstain from watching are correlated (Huysmans, Lammers, Renckstorf, and Wester, 2000) and that viewing (or non-viewing) by one partner triggers the other partner to do likewise (Westerik, Renckstorf, Wester, and Lammers, 2005).

\section{Television viewing in everyday life}

A critical assessment of $U \& G$ in its original form led to its reformulation in the Media use As Social Action approach (MASA, Renckstorf, 1996). This approach emphasizes that individuals are always embedded in a context of everyday life; they are constantly confronted with situations, which they are trying to master. This gives rise to subjective definitions of situations, meaning they will diagnose situations as problematic (they have not dealt with it before) or as non-problematic (they know how to deal with it).

If a situation is deemed non-problematic, individuals will invoke a routine response to deal with it almost without thinking. (For example: if someone is at home during the evening, feeling somewhat bored, s/he will usually not think very long before $\mathrm{s} / \mathrm{he}$ decides what to do; s/he will 
just turn on the television or the computer.) The other possibility is that a situation is deemed problematic (e.g., a marginal stock investor has become concerned about the value of his/her shares following the news earlier during the day). In that case, the person who experiences this problem will have to raise his/her awareness of the problem, conceive of possible solutions, make a decision, and implement it; and then evaluate the newly created situation (our marginal stock investor may discover business channels on his television). Apart from that, actions will constantly feed back to the make-up of the individual and his social environment, reinforcing or changing institutions and routines (our occasional shareholder may become a regular viewer of a business channel, thereby contributing to its financial success). Yet, those routines and institutions may be altered by new experiences occurring in everyday life.

Ang (1995) reviews examples of this newer approach of media use under the heading 'media in everyday life'. According to her, there is one common denominator in these newer studies in that they all address the question: 'How are the media integrated into our everyday lives?' ( $p$. 217). In our view this label is very well-suited for studies that try to go beyond uses and gratifications by paying attention to things such as routine behavior, group decision making, and situational constraint. To us, it is also attractive because the concept of everyday life links this study of audience research with theoretical approaches such as 'social constructivism' (Berger and Luckmann, 1966) and Schutzean action theory (Schutz and Luckmann, 1973; 1989), which treat 'everyday life' as a very central concept. For instance, Schutz and Luckmann (1973) open their first chapter by saying: 'The sciences that would interpret and explain human action must begin with a description of (...) the reality which seems self-evident for men remaining within the natural attitude. This reality is their everyday life-world' (p. 3).

At the heart of the concept of 'everyday life' in the Schutzean sense is its 'partial transcendency' (Westerik, Renckstorf, Lammers, and Wester, 2006). This means that actors in everyday life always experience themselves as both powerful and finite. 'The everyday life-world is the region of reality in which man can engage himself and which he can change while he operates (...) At the same time, the objectivities and events which are already found in this realm (including the acts and the results of actions of other men) limit his free possibilities of action' (Schutz and Luckmann, 1973, p. 3). This tension between reality as feasible for the actor, and reality as imposed on the actor, received too little attention in the initial U\&G conceptualizations of audience behavior. It focused too much on the feasibility aspect of everyday life, ignored the role played by the 'objectivities and events' in everyday life (including the role played by others), and the routines they use to deal with the transcendent aspects of the life-world. 


\section{Media use of adolescents and their parents}

Media use in childhood has been predicted with some success on the basis of parental and family characteristics that are not the result of choices made by the child itself. For example, Bianchi and Robinson (1997) explain differences in watching television, reading, and other activities on the basis of variables such as parental education, family income, maternal employment status, number of children, family composition, sibling position, and ethnicity. A similar practice can be found in studies of adolescent media use. Anderson, Huston, Schmitt, Linebarger, and Wright (2001) emphasize the role played by contextual characteristics in shaping media use, most notably the role played by parental education. Moreover, Roe (2000) argues that variables such as age, gender, ethnicity, and socioeconomic status, which are clearly imposed on the adolescent, have an important influence on adolescent media use.

One of the reasons behind the role played by such 'imposed' factors is, of course, the very process of socialization, which traditionally tends to be family specific (Roe, 2000; Berger and Berger, 1976). In part, this parental influence will be channeled through interaction between parents and their (adolescent) children (Berger and Luckmann, 1966). This follows also from research that indicates that the way in which parents interfere with their children's media use depends on the family background (Warren, Gerke, and Kelly, 2002). Parental interference is often studied under the labels of 'parental guidance' or 'parental mediation' (for a discussion of this concept, see Koolstra and Lucassen, 2004). These labels suggest that parental interference with media use by their (adolescent) children is deliberately induced with children's well-being in mind. In fact, Comstock and Scharrer (2001) argue that the most influence that parents have on their children's habitual media use is accidental. For instance, the unintended consequence of parents often being away from home, may be that their children will spend a lot of time in front of the television or playing video games. And parents may, of course, also interfere with their children's viewing based on selfish motives, for instance because their confirmation of power relations (cf. Morley, 1986).

All the same, it is clear that parents, by their example, by what they say, or just by being around, are likely to have an impact on their (adolescent) children's media use; and that this may have a lasting influence on their children's future habits. Furthermore, they may influence their (adolescent) children's media use by granting or withholding them access to the differing media and to resources that might substitute for media use (Bovill and Livingstone, 2001; Bianchi and Robinson, 1997). In addition to parental influences there is of course also the influence of others 
(teachers, grandparents, siblings, friends, peers) that may have an influence on media use by (adolescent) children. Because interaction with friends and peers is so important during adolescence (Breeuwsma, 1994), use of the differing media is likely to be deeply affected by the adolescent's relationship with friends and peers (cf. Bonfadelli, 1981; Eggermont, 2006; Bovill and Livingstone, 2001).

In sum then, it seems reasonable to conclude that others have considerable influence on media use of the (adolescent) child. Of course, this does not mean that such social influences are the only influences that count. On the contrary, there is convincing evidence that media use (and more specifically television viewing) also is influenced by more personal characteristics, such as the mental make-up of the child, his or her loyalty to friends, educational achievement, and school commitment (Comstock and Scharrer, 2001; Roe, 2000; Heim, Brandtzæg, Hertzberg Kaare, Endestad, and Torgersen, 2007). In addition, there is the influence of his or her past media use (the routinization that has taken place) and his or her existing structure of relevancies (including gratifications that are sought for, interests, and values; see Westerik et al., 2006; Renckstorf, 1996).

So, even in a time in which many adolescents have access to television and other media in the privacy of their own bedrooms (Bovill and Livingstone, 2001), it seems likely that both personal and social factors have an influence on media use by (adolescent) children. Some of these factors (e. g., the influence of parental co-presence) may be short-lived and immediate, other factors may have a lasting effect (e.g., socioeconomic status; Roe, 2000). And the effect of both social and personal factors is likely to vary as a function of age. During adolescence, human beings are expected to make a decision towards personal autonomy and selfreliance (e.g. Berger and Luckmann, 1966; Bronfenbrenner, 2001). As part of this process, adolescents are expected to invest in symmetrical relationships (with friends and peers), and less in asymmetrical relationships (with parents, Breeuwsma, 1994). Hence, parental interference with media use (or 'parental mediation', or 'parental guidance') is likely to become less frequent as the adolescent is growing older (Lin and Atkin, 1989).

At some point in time, most adolescents and young adults leave the parental home and start living alone or with a partner, or with others. In that case, direct parental influence on media use will, of course, be drastically reduced. Yet, even before the adolescent leaves the parental home s/he tries to escape parental influence (e.g., Gould, 1978). This desire may reduce the effectiveness of the parental interference with media use. In fact, one might even speculate that as adolescents grow older, 
'reverse socialization' effects (Van den Bulck and Van den Bergh, 2005) increasingly occur. In that case the influence of adolescents on parental media use would increase over the years.

\section{Research questions}

In the present study, which is part of a broader research project on the social embeddedness of media use (Westerik et al., 2005, 2006), we will focus on television use, because of its self-evident social significance. We will further focus on adolescence because of the possibly lasting effects of the habits acquired during this period (cf. Himmelweit and Swift, 1976) and, interesting from a theoretical point of view, because of the ambiguity of adolescents in their relationships to family life and parents. This makes it interesting to study how parental and adolescent television viewing are related, and how parents and their adolescent children influence each other in this respect.

Finally, we will focus on the everyday life family setting as it is at home where most of the television viewing takes place. From an action theoretical point of view, in which it is argued that action is usually codetermined by characteristics of the situations in which they take place (Schutz and Luckmann, 1973, p. 113-114; Westerik et al., 2006), it is thus very likely that characteristics of this setting will influence television viewing.

Accordingly, we will investigate television viewing with the above described perspective in mind. This means that we see television viewing not only as resulting from personal characteristics (e. g., gender, education, preferences) but also from social characteristics (e. g., parental education, household characteristics). Moreover, we expected that this is true for both adolescents and their parents. Therefore our first two research questions are:

$\mathrm{RQ}_{1}$ What are the social and personal antecedents of adolescent television viewing?

$\mathrm{RQ}_{2}$ What are the social and personal antecedents of parental television viewing?

Furthermore, building on the ideas that [a] media use is part of the totality of everyday life and thus reflects its overall changes, and that [b] this everyday life changes considerably during adolescence, we will further investigate:

$\mathrm{RQ}_{3}$ Do the antecedents of adolescent and parental viewing vary as a function of the age of the adolescent? 


\section{Method}

\section{Analysis}

In our theoretical framework it is assumed that household members have an influence on each other's actions, not just that their actions are correlated. This means we need to use either an experimental or a longitudinal design (cf. De Groot, 1969). Because we do not see how to apply an experimental design without compromising the everyday life setting, we are left only one option: applying a longitudinal design. In such a design one predicts some state of affairs or the occurrence of an event (A) at a certain moment in time ( $t$ ) on the basis of another a status or an event (B) at an earlier moment (t-1). Though this method offers no watertight guarantees for finding out the direction of causality, because their behavior at both $\mathrm{t}$ and $\mathrm{t}-1$ may have some common cause, this still seems to be the best way possible to get indications about the antecedents of media use.

The longitudinal method by which we analyzed our data is event history analysis, or more specifically, because the discrete nature of our data, logistic event modeling. In this analysis we predict the occurrence of an event with those who are 'at risk' of this event. This means that in our research we will predict viewing initiation only for those who are at risk of initiation, that is for those who are not already watching television. Likewise, we will only predict viewing termination for those who are viewing.

Parameters are estimated using logistic regression on data sets in which the person-period is the unit of analysis. The interpretation will therefore be similar to that of models in common logistic regression, with one notable difference: the model does not predict the probability that an event will happen to a person, but the conditional probability that an event will happen to a person in a particular interval.

To answer our research questions we carried out four separate multivariate analyses, one for every dependent variable (adolescent viewing initiation, adolescent viewing termination, parental viewing initiation, and parental viewing termination). Every single multivariate analysis was conducted in three consecutive stages. First stage analyses were aimed at finding a parsimonious model predicting viewing initiation or termination using a stepwise model selection procedure. Only time of the day, personal and household characteristics were allowed as predictors during these analyses. Subsequently, we carried out second stage analyses. In second stage analyses, variables retained from the preceding first stage analyses were entered as controls. Then variables indicative of characteristics of others were allowed to enter the equation, again by means of a stepwise procedure. Finally, third stage analyses were carried 
out aiming at exploring the moderating effect of age. This again was done by means of a stepwise procedure, in which interaction terms were now allowed. These terms measured the product of adolescent age on the one hand and predictors retained in first and second stage analysis on the other. In all stages, an alpha of .05 was used.

\section{Data}

We used data from a national probability survey held in the Netherlands during the first three months of 2000 by the Nijmegen Institute of Communication Research (cf. Konig et al., 2005). The initial study comprised 825 personal interviews with Dutch adults. As a follow-up to these interviews, respondents and their fellow household members aged 10 or older were asked to fill in additional written questionnaires and time-use diaries. A total of 287 households fully cooperated with this part of the study; in 121 households, some members did and others did not participate; in 7 households, we could not evaluate the completeness of the response; and in 410 households not a single person participated in the questionnaire and diary part.

For the diary, all participants were asked to answer open-ended questions regarding their time-use for each quarter of the day. These answers were subsequently coded into 11 broad activity categories ${ }^{3}$. Moreover, respondents were asked to indicate where and with whom they were during a specific quarter, whether or not they had watched TV, whether or not they had listened to radio or audio recordings, and whether or not they had been reading.

For this study, we analyzed diary data from the 55 households from which both parents and at least one child living at home had returned a time use diary. In our sample, the age of the sampled children ranged from nine years and nine months to 22 years and 11 months (with a mean of 14.5 year). Eighty-five percent of them fell within the age limits of 'adolescence' as defined by the World Health Organization (10-19 year olds; WHO, 1986), and 95 percent within the age limits of 'young people' as defined by an expert group for that same organization (1024 year olds; WHO, 1986). Although our sample does not perfectly match with the definition mentioned above, we choose to use the term 'adolescence' for our sample of persons still living with their parents in the parental home.

Data from 196 dairies were used: 55 diaries written by fathers, 55 by mothers, and 86 by children. From these dairies, only data from weekdays were used. 


\section{Data organization}

Based on the aforementioned data, we created a person-period sourcefile, which included a dummy-variable indicating for each recorded person-quarter whether or not a person had watched television during that quarter and whether or not s/he was at home during that quarter. This source consisted of 18,816 records, that is 196 respondents $\times 96$ quarters for each respondent. Based on this source file, we created four derivate files, the first explaining adolescent viewing initiation $(\mathrm{N}=4195)$, the second adolescent viewing termination $(\mathrm{N}=727)$, the third parental viewing initiation $(\mathrm{N}=5261)$, and the fourth parental viewing termination $(\mathrm{N}=$ $845)^{4}$.

\section{Variables}

In event history analysis, variables can be time-invariant (i.e., they are constant for all observations of a given individual) or time varying (i. e. for each individual, they can differ from observation to observation).

Dependent variables in our analyses were: adolescent viewing initiation, adolescent viewing termination, parental viewing initiation, and parental viewing termination. For quarters for which a person is 'at risk' of viewing, $\mathrm{s} / \mathrm{he}$ is allotted a ' 0 ' on viewing initiation if $\mathrm{s} / \mathrm{he}$ does not watch and a ' 1 ' if s/he does. Viewing termination is defined in a likewise manner, with ' 0 ' referring to continuation of viewing, and ' 1 ' to viewing termination.

Time invariant independent variables used in our analyses were:

- household characteristics such as household size ${ }^{5}$ and number of television sets at home ${ }^{6}$;

- demographics such as age of adolescent, father, and mother ${ }^{7}$, gender of adolescent ${ }^{8}$, education of adolescent, father and mother ${ }^{9}$;

- measures of what people see as important, such as paternal or maternal adherence to hedonistic values ${ }^{10}$, family values ${ }^{11}$, and egalitarian values $^{12}$; furthermore indicators of interests in specific subject such as news interest ${ }^{13}$, high culture interest ${ }^{14}$, interest in science and nature ${ }^{15}$, interest in sports ${ }^{16}$, interest in religion ${ }^{17}$, and interest in the weather ${ }^{18}$;

- measures of how adolescents and parents subjectively define their television viewing routines, such as viewing for surveillance ${ }^{19}$, viewing for seclusion $^{20}$, and viewing as socializing ${ }^{21}$;

- measures of habitual viewing styles, such as habitual dissonant viewing $^{22}$, habitual conversational viewing ${ }^{23}$, habitual co-viewing ${ }^{24}$; selective news viewing ${ }^{25}$, and exclusive news viewing ${ }^{26}$; 
- time budget measures, such as amount of participation ${ }^{27}$, amount of sports activities ${ }^{28}$, and amount of television viewing ${ }^{29}$.

All timevarying variables (except time of the day) were lagged, so that scores on independent variables were temporally antecedent to scores of dependent variables. Time-varying independent variables used in our analyses were:

- Time of the day ${ }^{30}$ and its squared value;

- measures indicative of being at home ${ }^{31}$, alone ${ }^{32}$, with children $^{33}$, with adult family ${ }^{34}$; or with non-family ${ }^{35}$;

- and measures indicative of spending time on sleeping and personal care $^{36}$, work, school and study ${ }^{37}$, household work and child care ${ }^{38}$, eating and drinking ${ }^{39}$, socializing, hobbies, and indoor games ${ }^{40}$, on sports, social, and cultural participation ${ }^{41}$, transportation ${ }^{42}$, reading ${ }^{43}$, listening to radio or audio ${ }^{44}, I C T$ use $e^{45}$, and watching television or video ${ }^{46}$.

\section{Results}

Before we present the main findings of our study, we will first present a general picture of viewing of our adolescents sample ${ }^{47}$. Figure 1 shows that viewing by adolescents peaks between 19:00 and 20:00. By then more than fifty percent of the adolescents in our sample are watching.

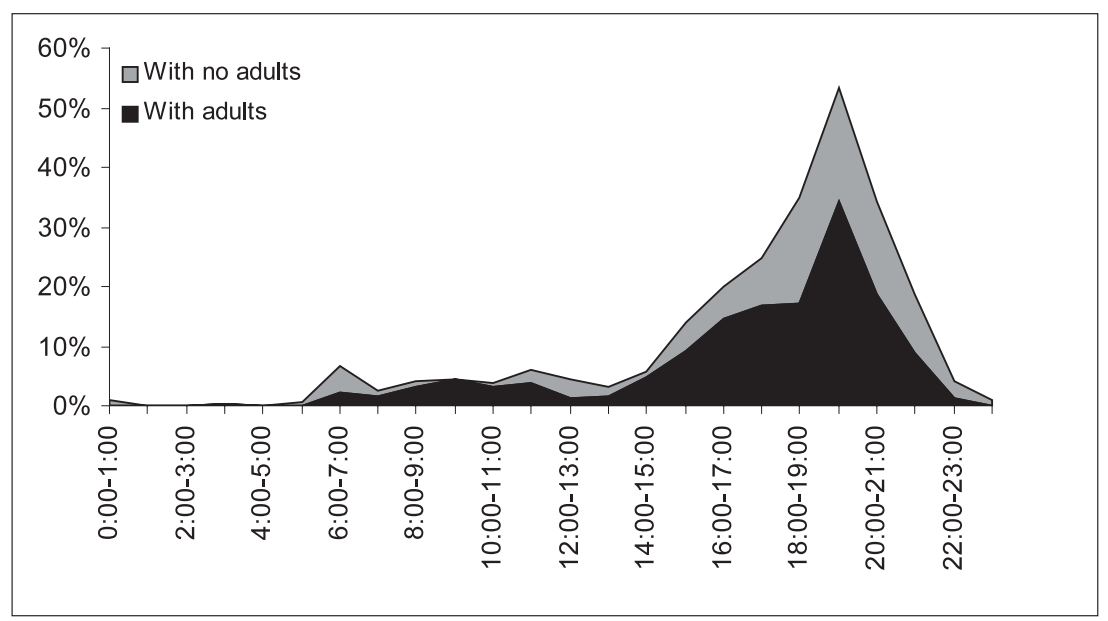

Figure 1. Percentage of adolescents viewing by co-presence of adults and time of the day $(N=91)$. 


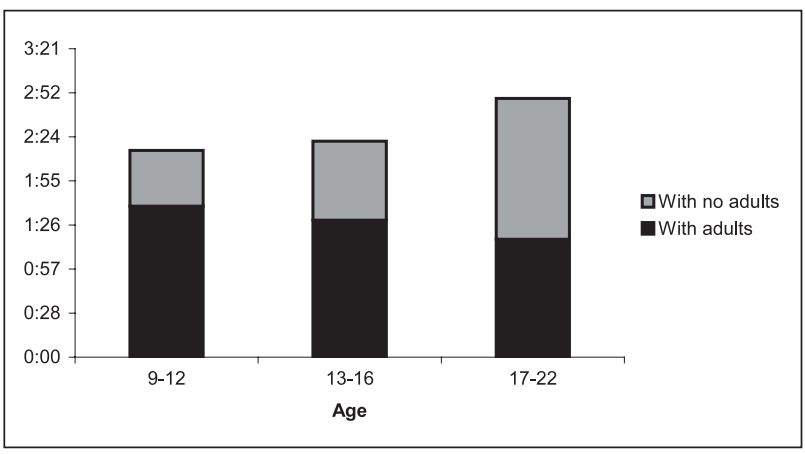

Figure 2. Adolescents' viewing time by co-presence of adults and age $(N=91)$.

Furthermore, we see that most adolescent viewing (approximately sixty percent) occurs in the co-presence of adult family members, and a somewhat smaller proportion in the co-presence of non-adults or alone. We can see that these two types of watching occur at roughly the same times $^{48}$.

In our sample, the difference between watching television in the presence of adults and watching television alone or with non-adults is clearly age-related. Older adolescents tend to spend most time in front of the television, but they spend least time watching television in the co-presence of adult family. For younger adolescents, the opposite is true. These findings thus suggest a developmental pattern in which adolescents increasingly develop a habit of watching television alone or with contemporaries, and decreasingly with adult family (father, mother); just as one should expect on the basis of the general theory of adolescence as a time of increasing (symmetrical) contact with contemporaries and decreasing (asymmetrical) contact with parents. However, even the oldest age group spends half of their viewing time in the co-presence of adult family. So, even for this group it seems interesting to analyze how their viewing is influenced by their parents and how they themselves influence parental viewing. In the subsequent event history analysis we will investigate how these activities of viewing are initiated and stopped by the social and personal characteristics of the individual.

\section{Adolescent viewing initiation}

Our final model predicting adolescent viewing initiation is presented in Table 1. In the first two rows, we see that time of the day does have a significant effect on viewing initiation. (Predicting adolescent viewing 
Table 1. Factors influencing children's viewing initiation at home $(N=4195$ personquarters; Nagelkerke's $R^{2}=27.9 \%$ ).

\begin{tabular}{|c|c|c|c|c|c|c|}
\hline & & B & S.E. & $\begin{array}{l}-2 \mathrm{LR} \\
\text { Change }\end{array}$ & $\mathrm{df}$ & Sig. \\
\hline Time & $\begin{array}{l}\text { Quarter } \\
\text { Quarter (squared) }\end{array}$ & $\begin{array}{r}.100 \\
-.001\end{array}$ & $\begin{array}{l}.0352 \\
.0004\end{array}$ & 11.39 & 2 & .003 \\
\hline Shared & Number of television sets & .450 & .0841 & 28.36 & 1 & .000 \\
\hline Child & $\begin{array}{l}\text { Viewing as seclusion } \\
\text { At home* } \\
\text { With adult family* } \\
\text { Sleeping and personal care* } \\
\text { Household work and child care* }\end{array}$ & $\begin{array}{r}.335 \\
-1.172 \\
.591 \\
-.916 \\
.856\end{array}$ & $\begin{array}{l}.1326 \\
.2540 \\
.1932 \\
.3465 \\
.2959\end{array}$ & $\begin{array}{r}6.16 \\
19.42 \\
9.38 \\
7.32 \\
7.45\end{array}$ & $\begin{array}{l}1 \\
1 \\
1 \\
1 \\
1\end{array}$ & $\begin{array}{l}.013 \\
.000 \\
.002 \\
.007 \\
.006\end{array}$ \\
\hline Father & $\begin{array}{l}\text { Age } \\
\text { Egalitarian values } \\
\text { Work, school and study* } \\
\text { Transportation* }\end{array}$ & $\begin{array}{r}-.045 \\
-.273 \\
-.797 \\
-1.848\end{array}$ & $\begin{array}{l}.0206 \\
.1151 \\
.2222 \\
.6194\end{array}$ & $\begin{array}{r}5.04 \\
5.88 \\
13.22 \\
14.24\end{array}$ & $\begin{array}{l}1 \\
1 \\
1 \\
1\end{array}$ & $\begin{array}{l}.025 \\
.015 \\
.000 \\
.000\end{array}$ \\
\hline Mother & $\begin{array}{l}\text { Habitual co-viewing } \\
\text { Sleeping and personal care* }\end{array}$ & $\begin{array}{r}.483 \\
-1.177\end{array}$ & $\begin{array}{l}.1321 \\
.4576\end{array}$ & $\begin{array}{r}14.17 \\
7.03\end{array}$ & $\begin{array}{l}1 \\
1\end{array}$ & $\begin{array}{l}.000 \\
.008\end{array}$ \\
\hline Constant & & -3.966 & 1.4477 & 7.50 & 1 & .006 \\
\hline
\end{tabular}

* Variable is lagged, it refers to situations or activities during previous quarter

a Note that the unit of analysis is the person-quarter (here the 4195 quarters during which our 86 child-respondents were at risk of starting to watch television).

initiation solely on the basis of time of the day and its square would result in a peak of viewing initiation at 15:30). It means that the chances of viewing initiation vary throughout the day, and are at their maximum during the afternoon.

From a theoretical point of view, the effect presented in the third row of Table 1 is rather interesting. Here we see that the number of television sets in a household is very important for understanding how often and how early adolescents start watching. The raw data from our sample ( $\mathrm{N}=4195$ person-quarters of adolescents) show that there is a clear linear relationship between number of television sets at home and the chances of starting or restarting television viewing while at home; for adolescents with 1, 2, 3, 4, and 5 television sets, observed chances for (re)initiation during the next quarter are 2, 3, 4, 6, and 8 percent provided they were not already viewing. This suggests that adolescents watch more television if they have more opportunities to watch privately. A similar conclusion can be drawn from the fourth row, which shows that adolescents who prefer to watch television in seclusion tend to start or restart viewing early. 
Our analysis further reveals some time-varying situational influences. If an adolescent was already at home the previous quarter, his/her chances of starting or restarting viewing are reduced. Because we here analyzed only quarters during which the adolescent was at home, this means viewing is often one of the first things that an adolescent starts doing after $\mathrm{s} / \mathrm{he}$ has arrived at home.

Unsurprisingly, we see that sleeping and personal care do have a negative effect on viewing initiation; they usually do not start watching if they are preparing to go to bed or if they are already asleep.

Furthermore we see that being with adult family has a positive effect on viewing. This suggests that family life also tends to promote television viewing, as a social event within the family, as earlier suggested by Hagen (1994) and Rothenbuhler (1985). This may seem somewhat odd because we earlier saw that privatization of media use is also enhancing viewing initiation. But there is apparently more than one pathway for adolescents towards watching television: privatization of television is one of pathway, but engagement in family life is another ${ }^{49}$.

Table 1 further reveals some parental influences as well. We see that adolescents whose father is relatively old are less likely to start viewing, and that having a father who adheres to egalitarian values reduces viewing initiation as well. So the identities of fathers are influencing viewing decisions made by their adolescent children. Apart from that, there is also an immediate effect of what they are doing on viewing initiation by their adolescent child. If fathers are at work or on the road, their children tend to postpone television viewing. An explanation for this is that a father at work or on the road cannot watch television, and thus they are less likely to trigger viewing by their adolescent children.

What mothers do also has an influence on viewing initiation by their adolescent child. Habitual co-viewing by the mother, the fact that she has a habit of watching television with others, has a positive effect on adolescent viewing initiation. Moreover, we find that if the mother has gone to bed (or is engaged in personal care) then the chances that her adolescent child will start watching television are reduced as well. So again we see that the family context of the adolescent may induce viewing.

Finally, we like to draw attention to two things that are not presented in Table 1. First, our data do not show that that adolescents start watching because their parents were already watching. That is apparently not the way in which parents influence their adolescents. It is the fact that other family members are around that triggers viewing initiation, not the specific fact that those other family members are watching television.

Second, our data do not show that the antecedents of viewing initiation change during adolescence. We added an age related interaction 
term for every main effect already found (so we entered age $\times$ quarter, age $\times$ quarter $^{2}$, age $\times$ number of television sets, etc. into the equation) but none of these interaction terms had any significant effect on the prediction of viewing initiation. So we did not find evidence supporting our theoretical assumption that the 'mechanisms' ${ }^{50}$ that trigger viewing change during adolescence.

\section{Adolescent viewing termination}

Turning now to adolescent viewing termination (Table 2), we see that the chances of viewing vary throughout the day. Regressing adolescent viewing termination solely on time of the day and its square results in a model that peaks at 16:00. This means that the chances of terminating a viewing session are at their minimum during the second half of the afternoon.

Again, we find several indications for the social character of television viewing. However, in contrast to what we found earlier there is now a negative relationship between family life and watching television. If an adolescent has a habit of watching with others and if his/her father is available (because he is neither sleeping nor engaged in sports, social

Table 2. Factors influencing children's viewing termination at home $(N=727$ personquarters; Nagelkerke's $R^{2}=11.7 \%$ ).

\begin{tabular}{|c|c|c|c|c|c|c|}
\hline & & B & S.E. & $\begin{array}{l}-2 \mathrm{LR} \\
\text { Change }\end{array}$ & $\mathrm{df}$ & Sig. \\
\hline Time & $\begin{array}{l}\text { Quarter } \\
\text { Quarter (squared) }\end{array}$ & $\begin{array}{r}-.189 \\
.002\end{array}$ & $\begin{array}{l}.0430 \\
.0000\end{array}$ & 19.95 & 2 & .000 \\
\hline Child & $\begin{array}{l}\text { Amount of participation } \\
\text { Habitual co-viewing }\end{array}$ & $\begin{array}{l}.110 \\
.317\end{array}$ & $\begin{array}{l}.0480 \\
.1080\end{array}$ & $\begin{array}{l}5.25 \\
9.10\end{array}$ & $\begin{array}{l}1 \\
1\end{array}$ & $\begin{array}{l}.022 \\
.003\end{array}$ \\
\hline Father & $\begin{array}{l}\text { Exclusive news viewing } \\
\text { Sleeping and personal care* } \\
\text { Sports, social and cultural } \\
\text { participation* } \\
\text { Listening to radio or audio* }\end{array}$ & $\begin{array}{r}.565 \\
-1.477 \\
-1.412 \\
1.017\end{array}$ & $\begin{array}{l}.1310 \\
.6270 \\
.5040 \\
.3400\end{array}$ & $\begin{array}{r}19.92 \\
7.17 \\
10.29 \\
8.16\end{array}$ & $\begin{array}{l}1 \\
1\end{array}$ & $\begin{array}{l}.000 \\
.007 \\
.001 \\
.004\end{array}$ \\
\hline Mother & $\begin{array}{l}\text { Egalitarian values } \\
\text { Selective news viewing }\end{array}$ & $\begin{array}{r}-.295 \\
.360\end{array}$ & $\begin{array}{l}.1400 \\
.1370\end{array}$ & $\begin{array}{l}4.61 \\
7.18\end{array}$ & $\begin{array}{l}1 \\
1\end{array}$ & $\begin{array}{l}.032 \\
.007\end{array}$ \\
\hline Constant & & -.361 & 1.2310 & .09 & 1 & .769 \\
\hline
\end{tabular}


or cultural participation) then s/he tends to terminate his/her viewing sessions earlier.

Another interesting finding in Table 2 is that viewing termination is positively related to more self-aware, goal-directed, deliberate types of action. Amount of participation is a positive predictor of termination, meaning that adolescents who are outgoing, who have a habit of visiting cinema, theater, ballet, concert or opera, exhibitions, museums, libraries, sporting events, amusement parks, or who went on an excursion or tourist trip, apparently tend to cut short their viewing episodes.

Early termination of viewing episodes is further enhanced by the parental news viewing styles. If an adolescent's father has a habit of watching the news without doing other things at the same time, and if an adolescent's mother exposes herself deliberately to newscasts, then the chances are high that the adolescent will be able to cut short his/her own viewing sessions.

Another finding in Table 2 is that viewing termination is enhanced if an adolescent's father is listening to the radio; perhaps that listening to the radio is 'hereditary' and that acts a substitute for watching television. A final finding in Table 2 is that adolescents whose mother adheres to egalitarian values tend to postpone viewing terminations. We do not see why this is so, perhaps it is a chance finding (but $p=.032$ ).

Again, we draw attention to the fact that adding age or age-related interaction terms do not result in a better model for prediction of viewing termination. So we conclude that age does not alter the mechanisms underlying adolescent viewing termination. And again, we see that parental viewing does not play a direct role; it does not inhibit or enhance viewing termination.

\section{Parental viewing initiation}

Leaving the case of adolescent viewing, we will look at what is causing television viewing by parents, and what role (adolescent) children play. We will first look at viewing initiation.

In Table 3, our final model predicting parental viewing initiation is presented. Again we see the significant impact of time of the day. Not surprisingly, our data indicate that parental viewing initiation peaks later than adolescent viewing initiation (18:00 vs. 15:30 respectively).

There are several similarities between parental and adolescent viewing initiation. A general pattern found earlier for adolescent viewing, namely that family life triggers viewing initiation, is re-emerging here. Again we see that viewing initiation is induced by arriving home, by the fact that an other household member has a habit of habitual co-viewing, and again we see that viewing initiation is delayed or postponed by sleeping 
Table 3. Factors influencing parental viewing initiation at home ${ }^{a}(N=5261$ personquarters; Nagelkerke's $R^{2}=28.2 \%$ ).

\begin{tabular}{|c|c|c|c|c|c|c|}
\hline & & B & S.E. & $\begin{array}{l}-2 \mathrm{LR} \\
\text { Change }\end{array}$ & $\mathrm{df}$ & Sig. \\
\hline Time & $\begin{array}{l}\text { Quarter } \\
\text { Quarter (squared) }\end{array}$ & $\begin{array}{l}.042 \\
.000\end{array}$ & $\begin{array}{l}.0278 \\
.0003\end{array}$ & 6.52 & 2 & .038 \\
\hline Parent & $\begin{array}{l}\text { Age } \\
\text { Interested in science and nature } \\
\text { Interested in sports } \\
\text { Habitual dissonant viewing } \\
\text { At home* } \\
\text { Idem } \times \text { age children } \\
\text { Sleeping and personal care* } \\
\text { Socializing, hobbies and } \\
\quad \text { indoor games* }\end{array}$ & $\begin{array}{r}-.057 \\
.320 \\
.232 \\
-.291 \\
1.211 \\
-.175 \\
-1.423 \\
-.520\end{array}$ & $\begin{array}{r}.0204 \\
.1207 \\
.0833 \\
.1236 \\
1.0139 \\
.0671 \\
.3646\end{array}$ & $\begin{array}{r}8.16 \\
7.13 \\
7.65 \\
6.01 \\
1.45 \\
6.87 \\
17.67\end{array}$ & $\begin{array}{l}1 \\
1 \\
1 \\
1 \\
1 \\
1 \\
1\end{array}$ & $\begin{array}{l}.004 \\
.008 \\
.006 \\
.014 \\
.229 \\
.009 \\
.000\end{array}$ \\
\hline $\begin{array}{l}\text { Other } \\
\text { parent }\end{array}$ & $\begin{array}{l}\text { Habitual co-viewing } \\
\text { Sleeping and personal care* } \\
\text { Work, school and study* } \\
\text { Eating and drinking* } \\
\text { Idem } \times \text { age children } \\
\text { Sports, social and cultural } \\
\quad \text { participation* } \\
\text { Idem } \times \text { age children } \\
\text { Watching television or video* }\end{array}$ & $\begin{array}{r}.245 \\
-1.139 \\
-.696 \\
-3.350 \\
.187\end{array}$ & $\begin{array}{r}.1109 \\
.3597 \\
.2463 \\
1.2822 \\
.0821\end{array}$ & $\begin{array}{r}5.01 \\
10.89 \\
8.54 \\
7.21 \\
5.03\end{array}$ & $\begin{array}{l}1 \\
1 \\
1 \\
1 \\
1\end{array}$ & $\begin{array}{l}.025 \\
.001 \\
.003 \\
.007 \\
.025\end{array}$ \\
\hline Children & $\begin{array}{l}\text { Amount of viewing } \\
\text { Work, school and study* } \\
\text { ICT use* } \\
\text { Watching television or video* }\end{array}$ & $\begin{array}{r}.002 \\
-.757 \\
-1.416 \\
.836\end{array}$ & $\begin{array}{l}.0007 \\
.2893 \\
.7828 \\
.2338\end{array}$ & $\begin{array}{r}4.46 \\
7.31 \\
4.44 \\
12.15\end{array}$ & $\begin{array}{l}1 \\
1 \\
1 \\
1\end{array}$ & $\begin{array}{l}.035 \\
.007 \\
.035 \\
.000\end{array}$ \\
\hline \multicolumn{2}{|c|}{$\begin{array}{l}\text { Age children } \\
\text { Constant }\end{array}$} & $\begin{array}{r}.127 \\
-4.133\end{array}$ & $\begin{array}{r}.0649 \\
1.4294\end{array}$ & $\begin{array}{r}3.82 \\
.87\end{array}$ & $\begin{array}{l}1 \\
1\end{array}$ & $\begin{array}{l}.051 \\
.352\end{array}$ \\
\hline
\end{tabular}

* Variable is lagged, it refers to situations or activities during previous quarter

a Note that the unit of analysis is the person-quarter (here the 5261 quarters during which our 110 parent-respondents were at risk of starting to watch television).

and personal care, and by work, school or study related activities of other household members.

We further see that the way in which family life is affecting parental viewing changes as a function of adolescent age. [a] For parents with younger children, arriving home does not trigger viewing initiation; but for parents with older children it does. [b] In families with younger (adolescent) children, the fact that one of the parents is having a meal hampers subsequent viewing initiation by the other parent. [c] In households with young adolescents, participation by one partner promotes viewing initiation by the other partner. In households with older adolescents, this effect does not occur. 
These moderating effects are not what we expected. We expected that older adolescents had more influence on viewing decisions than younger ones. However, what we observe is that they lose influence. An explanation for this may be that if (adolescent) children grow older, they apparently become more self-reliant, and by becoming more self-reliant, they free their parents from their responsibility to reckon with their children.

Furthermore, we see that some parental viewing initiation is triggered by some mechanisms that do not play a role in adolescents. Old age, feelings of guilt about watching too much television, and spending much time on socializing, hobbies and indoor games inhibit or postpone viewing only for parents. Also, unlike adolescents, parents are drawn early to television viewing by an interest in science and nature and/or in sport ${ }^{51}$

\section{Parental viewing termination}

Finally, in Table 4 we present our model predicting parental viewing termination. Again, we looked at the time of termination. Parental viewing termination is at it lowest at 17:30. For adolescents, it is at its lowest at 16:00, so again we see that parental viewing lags adolescent viewing.

Again, we see some evidence supporting the idea that family life and television viewing are positively related. If someone's partner is at home, then watching television may last long (but engagement in household work and child care also increase the likelihood of viewing termination). Unsurprisingly, again, we see that sleeping and personal care tend to cut short viewing episodes.

Table 4. Factors influencing parental viewing termination at home $(N=845$ personquarters; Nagelkerke's $R^{2}=10.3 \%$ ).

\begin{tabular}{llrrrrr}
\hline & & B & S.E. & $\begin{array}{l}\text {-2LR } \\
\text { Change }\end{array}$ & df & Sig. \\
\hline \multirow{2}{*}{ Time } & Quarter & -.152 & .0322 & 22.29 & 2 & .000 \\
& Quarter (squared) & .001 & .0003 & & & \\
Parent & Viewing as surveillance & .213 & .1029 & 4.33 & 1 & .037 \\
& Sleeping and personal care* & 1.131 & .4436 & 5.89 & 1 & .015 \\
& Household work and, child care* & .762 & .3611 & 4.09 & 1 & .043 \\
Other & Interested in the weather & -.357 & .1277 & 7.87 & 1 & .005 \\
parent & At home* & -.408 & .2021 & 3.98 & 1 & .046 \\
Children & Viewing as surveillance & -.260 & .0958 & 7.51 & 1 & .006 \\
& Constant & 3.494 & .9977 & 12.26 & 1 & .000 \\
\hline
\end{tabular}

* Variable is lagged, it refers to situations or activities during previous quarter

a Note that the unit of analysis is the person-quarter (here the 845 quarters during which our 110 parent-respondents were at risk of terminating their television viewing session), 
Furthermore, we find some results that are hard to explain. If parents see television viewing as their window to the world ('Viewing as surveillance') then they tend to watch short sessions. However, if their (adolescent) children see viewing as their window to the world, then parental viewing termination tends to be inhibited or postponed. Nor have we a clear picture as to why interest in the weather of one parents prolongs viewing by the other parent. All in all, we conclude that we have still a rather bleak picture of how parental viewing termination takes shape.

\section{Conclusion}

Answering our first and second research questions, we conclude that the most important social and personal antecedents of television viewing, for both parents and their adolescent children, have to do with aspects of family life. Connecting with other family members usually encourages television viewing initiation, and this is true for both parents and (adolescent) children. Yet there are some exceptions to this rule. In the first place we saw that contact with other family members is protecting adolescents from watching too long. In the second place we saw that parents of young children are sometimes hampered in watching television by their responsibilities for young children. However, the overall picture remains that family life fosters television viewing.

A second factor fostering television viewing is the privatization of television use. This factor only affects adolescents. Adolescents in households with many TV sets and adolescents who think that television viewing is something you have to do on your own start watching early. However, they do not stop early, so the privatization of television use clearly results in watching more television by adolescents. It does not affect parental viewing.

The answer to our third research question is that we found no evidence in support of our idea that the mechanisms underlying viewing change during adolescence. We did find some evidence that the mechanisms underlying parental viewing change during that period, but the nature of this change was expected. We expected that the adolescent would more and more assume an adult role, and as a result, would gain more influence on parental viewing decisions. However, what we found was that older adolescents where less reckoned with, probably because they thought they could care for themselves and did not need extra attention.

\section{Discussion}

Our findings clearly show that parents influence viewing behaviors of their adolescent children. Yet, parental influence seems to be a side-effect 
of the way in which parents organize their own lives (most notably their timing of work, sleep, participation, and transportation). This finding is very much in line with earlier work by Hamilton (1998) and Comstock and Scharrer (2001), who see adolescent viewing in part as an unintended consequence of parental conduct. Our findings further documented 'reverse socialization' effects as hypothesized by Van den Bulck and Van den Bergh (2005). The clearest example of this is our finding that if a teenager is watching television, s/he is also triggering his/her parents to do likewise. This is rather similar to the way in which parents influence each other.

On a more general level, our findings fit rather well into our action theoretical conceptualization of media use, formulated elsewhere (Renckstorf and Wester, 2004; Westerik et al., 2006). Our data show that both chronic situations imposed on the teenager (e.g., parental age, parental values, number of television sets at home) as well as transient ones (e. g., time of the day, co-presence of others, own activities, activities of parents) have their impact on viewing decisions by the teenager. Our data further confirm our ideas about television viewing as a social activity. Television viewing is clearly responsive to the influence of others.

Finally, we present some practical implications of our studies. From this point of view, the large impact that number of television sets at home has on teenagers' viewing initiation may be our most salient finding. This finding can be used as an empirical argument in support of pediatric recommendations to remove television sets from adolescent bedrooms (cf. AAP, 2001; Comstock and Scharrer, 2001). On the other hand, it casts doubt on the effectiveness of parental co-viewing and parental discussion of television programs as ways of restraining teenage television viewing. Discussion appeared to have no effect at all, while co-viewing had mixed effects. It appeared to stimulate teenage viewing initiation but it reduced the duration of viewing episodes. Duration of teenage viewing episodes was further restrained by selective and exclusive parental news viewing styles. So all in all, parents do have some influence on teenage television viewing; but teenagers do have an influence on parental viewing as well.

\section{Notes}

1. Aged two years and older

2. In Europe, the minimum age for being included in television use statistics is not uniform. It varies from 3 years old (Switzerland and Sweden) to 12 years old (Austria, Luxemburg, Norway).

3. In response to the questions "What were you doing? What else were you doing?" respondent could describe in their own words what they had done, during a given quarter. These answers were preliminary coded using the three digit code scheme 
introduced by Eurostat (2000) No difference was made between primary and secondary activities. Recoding of three-digit Eurostat codes into 10 broader activity categories was done by applying the following scheme: 010, 011, 012, 019, 530, 531 030, 031, 032, 033, $039 \rightarrow$ Sleeping and Personal Care; 020, 021, 022, $029 \rightarrow$ Eating and Drinking; 100, 110, 111, 112, 113, 119, 121, 122, 131, 133, 139, 141, 142, 149, 200, 210, 211, 212, 213, 219, 220, $221 \rightarrow$ Work, School, and Study ; 300, 310. $311,312,313,319,320,321,322,323,324,325,329,331,332,333,334,335$, $339,340,341,342,343,344,349,350,351,352,353,354,359,360,361,362,363$, $365,366,369,370,371,379,390380,381,382,383,384,385,386,387,389 \rightarrow$ Household Work and Child Care; 510, 511, 512, 513, 514, 519, 540, 364, 700, 710, 711, 712, 713, 719, 720, 721, 726, 722, 729, 730, 731, 732, 733, 734, 735, $739 \rightarrow$ Socializing, Hobbies and Indoor Games; 410, 411, 412, 419, 420, 421, 422, 423, $424,425,427,428,429,430,431,432,391,520,521,522,523,524,525,526,529$, $600,610,611,612,613,614,615,616,617,618,619,621,630,631 \rightarrow$ Sports, Social and Cultural participation; 800, 810, 811, 813, 814, 815, $819 \rightarrow$ Reading; $820,821,822,829 \rightarrow$ Watching Television or Video; 830, 831, 832, $839 \rightarrow$ Listening to Radio or Audio. 900 thru $994 \rightarrow$ Transportation. Note that the dummy for Watching Television or Video was not used as a predictor of the initiation or termination of someone's own television viewing; it was only used as a predictor of the initiation or termination television viewing by others.

4. For analyses explaining adolescent viewing, we only included person-quarters for adolescents (i.e. 86 persons $\times 96$ quarters per person $=8256$ person-quarters) minus the first quarters of days (because of incomplete data) minus the quarters for which respondents did not indicate to be at home. This resulted in a total of 4922 valid person-quarters. Because one cannot predict viewing initiation for adolescents already viewing, the adolescent viewing initiation file consists of 4195 records indicative of quarters during which adolescents were at risk of viewing. During the remaining 727 quarters they were at risk of viewing termination, so these quarters make up the adolescent viewing termination file. Both files with data on adolescent viewing were supplemented with predictor variables relating to own characteristics of the adolescent (e.g. adolescent age), and parental characteristics (e.g. father's age, mother's age). In a likewise fashion, we created files for analyzing parental viewing initiation and termination. So, we first created a set of 10560 parental person-quarters (based on 110 parents, each contributing 96 quarters) of which we retained 6355 quarters with valid scores for which parents had confirmed being at home. During 5261 of these quarters, they were at risk of viewing initiation, and during 845 quarters at risk of viewing termination. For the parental files, definition of viewing initiation and termination was identical to that used for the adolescent files. Yet, a slightly different procedure was used for adding predictor variables. In families with more than one adolescent, the adolescent related predictor variables were defined as the mean of valid scores for all adolescents (e.g., mean age adolescents).

5. Range 3 through $8 ; \mathrm{M}=4.3 ; \mathrm{SD}=1.01$.

6. Range 0 through $5 ; \mathrm{M}=2.4 ; \mathrm{SD}=1.09$.

7. Age of the 55 sampled fathers ranged from 32 thru $67(\mathrm{M}=46.5, \mathrm{SD}=5.82)$, that of the 55 mothers from 31 thru $66(\mathrm{M}=43.7, \mathrm{SD}=5.39)$, that of the 86 sampled 'adolescents' from 9 thru $22(\mathrm{M}=14.5$. $\mathrm{SD}=3.46)$.

8. The gender distribution among the sampled adolescents was $39.4 \%$ male $(=1)$ and $60.6 \%$ female $(=2)$. Gender of parents was used to categorize them as father or mother.

9. Education was measured ranging from unfinished primary school $(=1)$ through postgraduate education $(=10)$. It was defined as highest completed level for fa- 
thers $(\mathrm{M}=6.0, \mathrm{SD}=2.13)$ and mothers $(\mathrm{M}=5.18, \mathrm{SD}=1.87)$. For adolescents, it was defined as highest attended level of education $(\mathrm{M}=4.8, \mathrm{SD}=2.11)$.

10. No value orientations were measured for adolescents. All value orientations were measured using scales described by Scheepers, Schreuder, Felling, Peters, and Eisinga (1987). Fathers and mothers were asked to rate the importance of several items (varying from $1=$ Not important at all, to $5=$ very important). Adherence to hedonistic values was defined as the mean importance of 'having fun' and of 'enjoying life' for father $(\mathrm{M}=3.6$; $\mathrm{SD}=.84$; Cronbach's alpha $=.84)$ and mothers $(\mathrm{M}=4.0 ; \mathrm{SD}=.91$; alpha $=.83)$.

11. Family values was defined as the mean importance of 'a happy family life', 'having children', 'the future of my children', and 'paying attention to family life' for fathers $(\mathrm{M}=4.1 ; \mathrm{SD}=.63$; alpha $=.83)$ and mothers $(\mathrm{M}=4.3 ; \mathrm{SD}=.66$; alpha $=.83$ ).

12. Adherence to egalitarian values was defined as the mean perceived importance of 'commitment to a society in which everyone has a voice', 'contributing to reduction of income differences', 'breaking through relations of power', and 'promoting equality in society' for fathers $(\mathrm{M}=2.9 ; \mathrm{SD}=.89$; alpha $=.87)$ and mothers $(\mathrm{M}=2.9 ; \mathrm{SD}=.73$; alpha $=.83)$.

13. Interest were measured using scales ranging from 'no interest' (1) through 'very strong interest' (5). News interest was defined as the mean of interest in 'economy and finance', 'politics', 'employment and unemployment', 'adolescent education', 'accidents and disasters', 'celebrities', and 'current affairs and debates' for adolescents (alpha $=0.83 ; \mathrm{M}=2.2 ; \mathrm{SD}=0.73$ ), fathers (alpha $=0.55 ; \mathrm{M}=3.1$; $\mathrm{SD}=0.42$ ), and mothers (alpha $=0.47 ; \mathrm{M}=3 ; \mathrm{SD}=0.39$ ).

14. High culture interest was defined as the mean of the items measuring interest in 'classical music' and 'theatre plays and cabaret' for adolescents (alpha $=0.52$; $\mathrm{M}=2.1 ; \mathrm{SD}=0.93$ ), fathers (alpha $=0.44 ; \mathrm{M}=2.4 ; \mathrm{SD}=0.81$ ), and mothers (alpha $=0.55 ; \mathrm{M}=2.5 ; \mathrm{SD}=0.89$ ).

15. Interest in science and nature was defined as the mean of two items measuring interest in 'science' and 'nature' respectively for adolescents (alpha $=0.66 ; \mathrm{M}=$ 2.6; $\mathrm{SD}=1.08$ ), fathers (alpha $=0.64 ; \mathrm{M}=3.6 ; \mathrm{SD}=0.82$ ), and mothers (alpha $=0.54 ; \mathrm{M}=3 ; \mathrm{SD}=0.79$ ).

16. Interest in sports was measured with a single item for adolescents $(\mathrm{M}=3.1$; $\mathrm{SD}=1.31)$, fathers $(\mathrm{M}=3.1 ; \mathrm{SD}=1.22)$, and mothers $(\mathrm{M}=2.4 ; \mathrm{SD}=0.88)$.

17. Interest in religion was measured with a single item for adolescents $(\mathrm{M}=2.2$; $\mathrm{SD}=1.14)$, fathers $(\mathrm{M}=3.1 ; \mathrm{SD}=1.21)$, and mothers $(\mathrm{M}=3.2 ; \mathrm{SD}=1.12)$.

18. Interest in the weather was measured with a single item for adolescents $(\mathrm{M}=2.8$; $\mathrm{SD}=1.14)$, fathers $(\mathrm{M}=3.4 ; \mathrm{SD}=0.91)$, and mothers $(\mathrm{M}=3.6 ; \mathrm{SD}=0.66)$.

19. Viewing for surveillance was measured as agreeing $(1=$ totally disagree, $5=$ totally agree) with 'television for me is a window to the world' for adolescents $(\mathrm{M}=2.6$; $\mathrm{SD}=1.08)$, fathers $(\mathrm{M}=3.1, \mathrm{SD}=.92)$, and mothers $(\mathrm{M}=3.1 ; \mathrm{SD}=.88)$.

20. Viewing for seclusion was measured as agreeing with 'Television viewing is something you must do when there are no others around' for adolescents $(\mathrm{M}=1.9$; $\mathrm{SD}=.74)$, fathers $(\mathrm{M}=2.1, \mathrm{SD}=.69)$ and mothers $(\mathrm{M}=2.0 ; \mathrm{SD}=.69)$.

21. Viewing as socializing was measured as agreeing with 'I like sitting with the whole household nicely around the television set' for adolescents $(\mathrm{M}=3.5 ; \mathrm{SD}=1.04)$, fathers $(\mathrm{M}=3.4, \mathrm{SD}=.83)$ and mothers $(\mathrm{M}=3.4 ; \mathrm{SD}=.90)$.

22. Habitual dissonant viewing was defined as the frequency of 'being sorry for having watched television the whole evening $(1=$ never, $5=$ almost always), for adolescents $(\mathrm{M}=1.7 ; \mathrm{SD}=.74)$, fathers $(\mathrm{M}=2.0 ; \mathrm{SD}=.72)$, and mothers $(\mathrm{M}=1.9$; $\mathrm{SD}=.77)$.

23. Habitual conversational viewing was defined analogous as the frequency of 'talking with other household members about what I in that moment see on television', 
for adolescents $(\mathrm{M}=2.3 ; \mathrm{SD}=.77)$, fathers $(\mathrm{M}=2.5 ; \mathrm{SD}=.89)$, and mothers $(\mathrm{M}=2.3 ; \mathrm{SD}=.72)$.

24. Habitual co-viewing was defined as mean of responses on two items 'of the times you are watching television, how often do you watch with fellow household members' ( $1=$ never, $5=$ almost always $)$, and the reversed coded 'of the times you are watching television, how often do you watch alone', for adolescents (alpha = $.67 ; \mathrm{M}=3.6 ; \mathrm{SD}=.98)$, fathers (alpha $=.69 ; \mathrm{M}=3.8 ; \mathrm{SD}=.78$ ), and mothers (alpha $=.83 ; \mathrm{M}=3.8 ; \mathrm{SD}=.79$ ).

25. Selective news viewing was measured as the mean of three items ('I keep track with time not to miss the TV news', 'I plan the evening not to miss the TV news', 'I watch the news attentively from start to finish') for adolescents (alpha $=.80$; $\mathrm{M}=3.7 ; \mathrm{SD}=.81$ ), for fathers (alpha $=.46 ; \mathrm{M}=2.9 ; \mathrm{SD}=.79$ ), and mothers (alpha $=.68 ; \mathrm{M}=3.0 ; \mathrm{SD}=.82$ ). Answers varied from 'Does not apply at all' (1) to 'Applies to me entirely' (5).

26. Exclusive news viewing was based on three items as well: 'I often read while watching TV News'; 'My mind wanders about during watching TV News'; 'I talk about other things while watching TV news' for adolescents (alpha $=.68 ; \mathrm{M}=3.8$; $\mathrm{SD}=.71)$, fathers $($ alpha $=.82 ; \mathrm{M}=3.1 ; \mathrm{SD}=.97)$, and mothers (alpha $=.80$; $\mathrm{M}=2.9 ; \mathrm{SD}=.90)$. Original codings are reversed here.

27. Amount of participation was measured by asking fathers, mothers and adolescents how often during the last four weeks they went to 'the cinema'; 'theater, ballet, concert or opera', 'an arts exhibition or a museum', 'a library', 'as a spectator to a sporting event', 'on a excursion, a tourist trip, or to an amusement park', and then summing up the answers for adolescents $(\mathrm{M}=2,7 ; \mathrm{SD}=2,13)$, fathers $(\mathrm{M}$ $=1.7 ; \mathrm{SD}=1.95)$, and mothers $(\mathrm{M}=4.3 ; \mathrm{SD}=12.48)$.

28. Amount of sports activities was measured in a similar way. So, respondents had to indicate how often during the last four weeks they engaged in 'jogging, running, walking as a sport', 'cycling as a sport', 'skiing', 'swimming as a sport', 'gymnastics', 'ballgames', or 'rowing, yacht racing, windsurfing' and then their answers were summed, resulting scores for adolescents $(\mathrm{M}=5.8 ; \mathrm{SD}=6.76)$, fathers $(\mathrm{M}$ $=7,6 ; \mathrm{SD}=8,01)$, and mothers $(\mathrm{M}=10,3 ; \mathrm{SD}=21,88)$.

29. Amount of television viewing, which was measured as the reported average amount of watching television and video's in minutes per day, for adolescents $(M=170$; $\mathrm{SD}=105)$, fathers $(\mathrm{M}=149 ; \mathrm{SD}=115)$, and mothers $(\mathrm{M}=143 ; \mathrm{SD}=84)$.

30. Time of the day was defined using rank numbers of quarters starting with 1 (4:004:15) and ending with 96 (3:45-4:00 of the following day) and its square. We did not predict viewing initiation and termination for quarter 1 , because we predicted initiation and termination on the basis of variables relating to the previous quarter, and no data on the quarter before quarter 1 were available.

31. This and the subsequent variables were all dummy coded $(0=$ no, $1=$ yes $)$. Note that we analyzed only predicted a persons initiation and termination for quarters that $\mathrm{s} / \mathrm{he}$ was at home, and that not all actors had the same probability of being at home. Adolescents were $57.2 \%$ of the sampled time at home, fathers $51.4 \%$, and mothers $65.5 \%$. This does not mean that the variable at home is constant for the person whose television viewing is predicted because the at home variable is lagged. When at home, respective chances of being at home during the previous quarter were $96.4 \%, 96.2 \%$, and $95.7 \%$ for adolescents, fathers, and mothers.

32. True for $47.4 \%, 14.7 \%$, and $17.8 \%$ of the time spent at home by adolescents, fathers, and mothers respectively.

33. True for $6.4 \%, 4.2 \%$, and $9.2 \%$ of the time (see note 32 ).

34. True for $39.1 \%, 73.5 \%$, and $67.4 \% \%$ of the time (see note 32 ).

35. True for $6.0 \%, 4.9 \%$, and $5.9 \%$ of the time (see note 32 ). 
36. True for $60.0 \%, 52.1 \%$, and $42.9 \%$ of the time (see note 32 ).

37. True for $5.0 \%, 4.7 \%$, and $2.2 \%$ of the time (see note 32 ).

38. True for $2.5 \%, 8.0 \%$, and $25.2 \%$ of the time (see note 32 ).

39. True for $7.2 \%, 9.0 \%$, and $11.7 \%$ of the time (see note 32 ).

40. True for $8.4 \%, 8.9 \%$, and $9.4 \%$ of the time (see note 32 ).

41. True for $0.5 \%, 0.7 \%$, and $0.2 \%$ of the time (see note 32 ).

42. True for $2.5 \%, 1.9 \%$, and $2.2 \%$ of the time (see note 32 ).

43. True for $0.3 \%, 4.2 \%$, and $2.8 \%$ of the time (see note 32 ).

44. True for $4.4 \%, 7.2 \%$, and $10.1 \%$ of the time (see note 32 ).

45. True for $1.9 \%, 2.1 \%$, and $0.8 \%$ of the time (see note 32 ).

46. True for $14.8 \%, 16.4 \%$, and $11.8 \%$ of the time (see note 32 ).

47. The sample size here is 91 , in the event history analysis 86 (because of missing data). Note that the ages of the 'adolescents' in our sample range from 9 to 22 years.

48. The correlation between the average percentage of adolescents watching alone per hour with the percentage of adolescents watching in the co-presence of adult household members per hour is $.90(\mathrm{~N}=24$; $\mathrm{P}<.001)$.

49. Another indication for the close connection between engagement in family life and viewing initiation is the positive effect of doing household work on subsequent viewing initiation.

50. Or to put it more precisely: the routines.

51. Note that in the row before the last row of Table 3, a non-significant effect of adolescent age is presented. We did not remove this effect because we could otherwise not determine the significance of interaction effects involving the 'young adolescents' variable.

\section{References}

AAP. (2001). Children, adolescents, and television. Pediatrics, 107, 423-426.

Anderson, C. A. and Bushman, B. J. (2002). The effects of media violence on society. Science, 295, 2377-2379.

Anderson, D. R., Huston, A. C., Schmitt, K. L., Linebarger, D. L., and Wright, J. C. (2001). Media use in adolescence. Monographs of the Society for Research in Child Development 66(1), 25-35.

Ang, I. (1995). The nature of the audience. In J. Downing, A. Mohammadi, and A. Sreverny-Mohammadi (Eds.) Questioning the media: A critical introduction. (pp. 155-165) Thousand Oaks, CA:Sage.

Berger, P. L. and Luckmann, T. (1966). The social construction of reality: A treatise in the sociology of knowledge. London: Penguin Books.

Berger, P. L. and Berger, B. (1976). Sociology: A biographical approach. Harmondsworth: Penguin.

Bianchi, S. M. and Robinson, J. (1997). What did you do today? Children's use of time, family composition, and the acquisition of social capital. Journal of Marriage and the Family 59, 332-344.

Blumler, J. (1979). The role of theory in uses and gratifications studies. Communication Research, 6, 9-36.

Bonfadelli, H. (1981). Die Sozialisationsperspektive in der Massenkommunikation: Neue Ansätze, Methoden und Resultate zur Stellung der Massenmedien im Leben der Kinder und Jugendlichen. Berlin: Spiess.

Bovill, M. and Livingstone, S. (2001). Bedroom culture and the privatization of media use. In S. Livingstone and M. Bovill (Eds.), Children and their changing media 
environment: A European comparative study (pp. 179-200). London: Lawrence Erlbaum Associates.

Breeuwsma, G. (1996). De constructie van de levensloop. [The construction of the lifecourse]. Amsterdam: Boom.

Bronfenbrenner, U. (2001). The bioecological theory of human development. In N. J. Smelser and P. B. Baltes (Eds.), International encyclopedia of the social and behavioural sciences (pp. 6963-6970). Oxford: Elsevier.

Bryant, J. and Miron, D. (2004) Theory and research in mass communication. Journal of Communication, 54, 662-704.

Comstock, G. and Scharrer, E. (2001). Use of television and other film-related media. In D. Singer and J. Singer (Eds.), Handbook of children and the media. Thousand Oaks, CA: Sage, pp. 47-72.

Comstock, G. and Scharrer, E. (1999). Television: What's on, who's watching, and what it means. San Diego, CA: Academic Press.

De Groot, A. D. (1969). Methodology. Foundations of inference and research in the behavioral sciences. The Hague-Paris: Mouton and Co.

Eggermont, S. (2006). Developmental changes in adolescents' television viewing habits: Longitudinal trajectories in a three-wave panel. Journal of Broadcasting and Electronic Media, 50, 742-761.

Elliot, P. (1974). Uses and gratification research: A critique and a sociological alternative. In J. G. Blumler and E. Katz (eds.), The uses of mass communications: Current perspectives on gratifications research, pp. 249-269. Beverly Hills, CA: Sage.

Eurostat. (2000). Survey on time use: Activity coding list. Final draft. Doc E2/ TUS/5/00. http://unstats.un.org/unsd/methods/timeuse/tusresource_manuals/euro stat_man.pdf (accessed September 20, 2004).

European Audiovisual Observatory (2003). Yearbook 2003, Volume 2: Household audiovisual equipment - transmission - television audience. Strasbourg: European Audiovisual Observatory.

Goodhardt, G. J., Ehrenberg, A. S. C., and Collins, M. A. (1975). The television audience. Farnborough: Saxon House.

Gould, R. L. (1978). Transformations: Growth and change in adult life. New York: Simon and Schuster.

Hagen, I. (1994). Expectations and consumption patterns in TV news viewing. Media, Culture and Society, 16, 415-428.

Hancox, R. J., Milne, B. J., and Poulton, R. (2004). Association between child and adolescent television viewing and adult health: a longitudinal birth cohort study. The Lancet, 364, 257-262.

Hancox, R. J., Milne, B. J., and Poulton, R. (2005). Association of television viewing during childhood with poor educational achievement. Archives of Pediatrics and Adolescent Medicine, 159, 614-618.

Hancox, R. J. and Poulton, R. (2006). Watching television is associated with childhood obesity: but is it clinically important? International Journal of Obesity, 30, $171-175$.

Hamilton, J. T. (1998). Channeling violence: The economic market for violent television programming. Princeton, N. J. : Princeton University Press.

Heim, J., Brandtzæg, P. B., Kaare, B. H., Endestad, T., and Torgersen, L. (2007). Children's usage of media technologies and psychosocial factors. New Media and Society 9 (3): 425-454.

Himmelweit, H. and Swift, B. (1976). Continuities and discontinuities in media usage and taste: A longitudinal study. Journal of Social Issues, 32, 133-156.

Huysmans, F. (1996). Social time and media use. Communications, 21(4), 483-505. 
Huysmans, F. J. M., Lammers, J. G. M., Renckstorf, K., and Wester, F. P. J. (2000). Television viewing and the temporal organization of daily life in households: A multilevel analysis. Communications, 25(4), 357-370.

Johnson, J., Cohen, P., Smailes, E., Kasen, S., and Brook, J. (2002). Television viewing and aggressive behavior during adolescence and adulthood. Science, 295, 24682471.

Katz, E., Blumler, J. G., and Gurevitch, M. (1974). Utilization of mass communication by the individual. In J. G. Blumler and E. Katz (Eds. ) The uses of mass communications: Current perspectives on gratifications research (pp. 19-32). Beverly Hills, CA: Sage.

Konig, R. P., Jacobs, H. A. G. M., Hendriks Vettehen, P. G. J., Renckstorf, K., and Beentjes, J. W. J. (2005). Media use in the Netherlands 2000: Documentation of a national survey. Den Haag: DANS

Konig, R. P. Renckstorf, K., and Wester, F. (2001). On the use of television news: Routines in watching the news. In K. Renckstorf, D. McQuail, and N. Jankowski (Eds.), Television news research: Recent European approaches and findings (pp. 147-171). Berlin: Quintessenz Books.

Koolstra, C. M. and Lucassen, N. (2004). Viewing behavior of children and TV guidance by parents: A comparison of parent and child reports. Communications, 29, 179-98.

Levy, M. R. (1983). Conceptualizing and measuring aspects of audience 'activity'. Journalism Quarterly, 60, 109-115.

Lin, C. and Atkin, D. J. (1989). Parental mediation and rulemaking for adolescent use of television and VCRs. Journal of Broadcasting and Electronic Media, 33(1), $53-67$.

Lull, J. (1988). The family and television in world cultures. In J. Lull (Ed.), World families watch television (pp. 9-21). London: Sage.

Morgan, M. (1993). Television and school performance. Adolescent Medicine: State of the Art Reviews, 4(3), 607-622.

Morley, D. (1986). Family television: Cultural power and domestic leisure. London: Comedia.

Mutsaers, W. (1996). Television viewing as social activity. In K. Renckstorf, D. McQuail, and N. W. Jankowski (Eds.), Media use as social action: a European approach to audience studies (pp. 87-102). London: John Libbey.

Nielsen Media Research. (2005, September). News release: Nielsen reports Americans Watch TV at record levels. Retrieved August 9, 2007, from http://www. nielsenmedia. com/newsreleases/2005/AvgHoursMinutes92905.pdf

Renckstorf, K. (1989). Mediennutzung als soziales Handeln: Zur Entwicklung einer handlungstheoretischen Perspektive der empirischen (Massen-) Kommunikationsforschung. Kölner Zeitschrift für Soziologie und Sozialpsychologie, Sonderheft Massenkommunikation, 30, 314-336.

Renckstorf, K. (1996). Media use as social action: A theoretical perspective. In K. Renckstorf, D. McQuail, and N. Jankowski (Eds.), Media use as social action: A European approach to audience studies (pp. 18-31). London: John Libbey.

Renckstorf, K. and Wester, F. (2004). The 'media use as social action approach': Theory, methodology, and research evidence so far. In K. Renckstorf, D. McQuail, J. Rosenbaum, and G. Schaap (Eds.). Action theory and communication research: Recent developments in Europe (pp. 51-83). Berlin: Mouton De Gruyter.

Roe, K. (2000). Adolescents' media use: A European review. Journal of Adolescent Health $27 S$, pp. 15-21.

Rosengren, K. E. (1974). Uses and gratifications: A paradigm outlined. In J. G. Blumler and E. Katz (Eds.), The uses of mass communications (pp. 167-196). Beverly Hills: Sage. 
Rothenbuhler, E. W. (1985). Media events, civil religion, and social solidarity: The living room celebration of the Olympic Games. Los Angeles, CA: University of Southern California. Ph. D. Thesis.

Rubin, A. M. (1984). Ritualized and instrumental television viewing. Journal of Communication, 34(3), 67.

Rubin, A. M. (2002). The uses and gratifications perspective of media effects. In J. Bryant and D. Zillman (Eds.), Media Effects: Advances in Theory and Research (2nd ed). p. 525-548. New Jersey: Lawrence Erlbaum.

Scheepers, P. L. H., Schreuder, O., Felling, A., Peters, J., and Eisinga, R. (1987). Religion in Dutch society 85: Documentation of a national survey on religious and secular attitudes in 1985. Amsterdam: Steinmetz.

Schutz, A. and Luckmann, T. (1973). The structures of the life world (Volume 1). Evanston: North Western University Press.

Schutz, A. and Luckmann, T. (1989). The structures of the life world (Volume 2). Evanston: North Western University Press.

Van den Bulck, J. and Van den Bergh, B. (2005). The child effect in media and communication research: A call to arms and an agenda for research. In P. J. Kalbfleisch (Ed.). Communication Yearbook 29, pp. 47-72. Mahwah, NJ: Lawrence Erlbaum Associates.

Vandewater, E. A., Bickham, D. S., Lee, J. H., Cummings, H. M., Wartella, E. A., and Rideout, V. J. (2005). When the television is always on: Heavy television exposure and young children's development. American Behavioral Scientist, 48, $562-577$.

Warren, R., Gerke, P., and Kelly, M. A. (2002). Is there enough time on the clock? Parental involvement and mediation of children's television viewing. Journal of Broadcasting and Electronic Media, 46, 1, 87-111.

Webster, J. G., and Wakshlag, J. J. (1982). The impact of group viewing on patterns of television program choice. Journal of Broadcasting, 26, 445-455.

Westerik, H., Renckstorf, K., Wester, F., and Lammers, J. (2005). The situational and time-varying context of routines in television viewing: An event history analysis. Communications, 30, 155-182.

Westerik, H., Renckstorf, K., Wester, F. and Lammers, J. (2006). Transcending Uses and Gratifications: Media use as social action and the use of event history analysis. Communications, 31(2), 139-153.

WHO. (1986). Young people's health - a challenge for society: Report of a WHO study group on young people and 'Health for all by the year 2000'. Geneva: Word Health Organization. 